\title{
Surface applied lime dynamics and base saturation index in a consolidated no-tillage area
}

\author{
Diego Bortolini*1, Luís César Cassol ${ }^{2}$, Jonatas Thiago Piva ${ }^{3}$, Cristiam Bosi ${ }^{4}$, Kassiano Felipe Rocha ${ }^{5}$
}

\author{
'University of Santa Catarina State, Lages, Brazil \\ ${ }^{2}$ Federal Technological University of Paraná, Pato Branco, Brazi \\ ${ }^{3}$ Federal University of Santa Catarina, Curitibanos, Brazil \\ ${ }^{4}$ University of Sao Paulo, Piracicaba, Brazil \\ *Corresponding author, e-mail: diegobertanbortolini@gmail.com
}

\begin{abstract}
The aim of this study was to evaluate the behavior of chemical properties and crop yields during five years after liming, in a consolidated no-tillage system area and indicate a base saturation index to serve as a criterion for recommendation. The experiment was conducted in a randomized complete block design with four repetitions, being the treatments the five lime doses $(0,2.4,4.8,7.2$ and 9.6 $\mathrm{Mg} \mathrm{ha}^{-1}$ ) applied and maintained on the soil surface. Soil chemical properties were evaluated in eight soil sampling, in the layers 0 to $0.025 ; 0.025$ to $0.05 ; 0.05$ to $0.10 ; 0.10$ to $0.15 ; 0.15$ to 0.20 and 0.20 to $0.40 \mathrm{~m}$, besides crop grain yield (wheat, soybean and corn) and black oat dry matter yield, totaling five years of evaluation. The surface liming in no-tillage system increased the exchangeable magnesium and calcium contents, base saturation and soil $\mathrm{pH}$ and reduced the exchangeable aluminum content. The cumulative grain yield (six crops) and black oat dry matter yield (three crops) was not influenced by liming. These results suggested, from this study conditions, that the value of $50 \%$ of base saturation should be adopted as a criterion for liming for crops implanted under consolidated no-tillage systems.
\end{abstract}

Key words: Aluminium, Liming, Chemical characteristics, Liming recommendation.

\section{Dinâmica do calcário aplicado superficialmente e índice de saturação por bases em plantio direto consolidado}

\section{Resumo}

O objetivo foi avaliar o comportamento das propriedades químicas do solo e rendimento de culturas ao longo de cinco anos após calagem, em sistema de plantio direto consolidado, e sugerir um índice de saturação por bases que sirva de critério para recomendação. O experimento foi conduzido num delineamento de blocos ao acaso, com quatro repetições, sendo que os tratamentos foram cinco doses de calcário $\left(0,2,4,4,8,7,2\right.$ e 9,6 $\left.\mathrm{Mg} \mathrm{ha}^{-1}\right)$ aplicadas em superfície. Avaliaram-se os atributos químicos do solo em oito coletas de solo, nas camadas de 0,0 a 0,025;0,025 a 0,05; 0,05 a 0,$10 ; 0,10$ a 0,15; 0,15 a 0,20 e 0,20 a 0,40 m e a produtividade de grãos das culturas (trigo, soja e milho) e a massa seca de aveia preta, totalizando cinco anos de avaliação. A calagem superficial em sistema plantio direto aumentou os teores de magnésio e cálcio trocáveis, saturação por bases e o pH do solo e reduziu o teor de alumínio trocável. A calagem não elevou os rendimentos acumulados tanto de grãos (seis cultivos), como de massa seca de aveia (três cultivos). Sugere-se, a partir das condições encontradas neste trabalho, que o valor de 50\% de saturação por bases seja adotado como critério de calagem para as principais culturas implantadas sob sistema de plantio direto consolidado.

Palavras-chave: Alumínio, Calagem, Características químicas, Recomendação de calagem. 


\section{Introduction}

In order to decide whether to apply lime or not, indicators like $\mathrm{pH}$, aluminum (exchangeable or its saturation) and base saturation may be used, and for the definition of dosage, methods like potential acidity, the SMP index and the formulae that involve factors and/ or acidity components may be adopted (Nolla \& Anghinoni, 2006; Nolla et al., 2005; Nicolodi et al., 2008). The state of Parana adopts the method of base saturation, recommending liming when the saturation is lower than $70 \%$. This value was developed under conventional tillage systems for the majority of crops; currently, however, no-tillage system is used in the largest portion of cultivated areas with summer crops.

Areas that are cultivated for long time in no-tillage system show an increase in organic matter content and higher production of organic binding agents; higher aluminum complexation, reducing its activity, phytotoxic effect and soil acidity, especially in the surface layer (Diehl et al., 2008).

This different aluminum dynamics in cultivated soils under no-tillage system results in lower response of crops to liming (Pöttker \& Ben, 1998). Knowledge of the acidity dynamics over time in no-tillage areas, from the soil surface until deeper layers, is required to establish adjustments in liming recommendations and in the frequency of correctives re-application (Amaral \& Anghinoni, 2001). Thus, the utilization of liming criteria from the conventional tillage system overestimates the need of liming in the no-tillage system (Nolla \& Anghinoni, 2006).

The lime application on the soil surface has a significant effect increasing $\mathrm{pH}$, calcium and magnesium content and base saturation, besides reducing potential acidity in the soil surface (Pöttker \& Ben 1998; Caires et al., 2015; Veronese et al., 2012; Schoninger et al., 2010) as well as in the subsurface (Diehl et al., 2008). It may also alter $\mathrm{pH}$ and aluminum content beyond a depth of $60 \mathrm{~cm}$ (Chatzistathis et al., 2015; Mosquera-Losada et al., 2015; Pagani \& Mallarino, 2015).

According to these informations, soils cultivated over time in no-tillage system will present a different response to lime application since they have higher organic matter content, which is responsible for the complexation of the aluminum of the soil. It is possible to maintain high productivity with a base saturation below $70 \%$ in a consolidated no-tillage system. The objective of this study is to assess the behavior of soil chemical properties and crops yield during five years after liming, in a consolidated no-tillage area, suggesting a base saturation index that could provide a criterion for liming recommendation.

\section{Material and Methods}

The experiment was carried out in Pato Branco, PR, Brazil, in a typical Dystrophic Red Oxisol (Embrapa, 2013) with very loamy texture (627 $\mathrm{g} \mathrm{kg}^{-1}$ clay, $252 \mathrm{~g} \mathrm{~kg}^{-1}$ silt and $121 \mathrm{~g} \mathrm{~kg}^{-1}$ sand). The area was being cultivated in no-tillage system since 1999. In 2005 wheat was grown in the winter and the experiment started at the end of its cycle. Before the treatments beginning, a soil sample from 0.00-0.20m was taken for chemical characterization, with the following results: $\mathrm{pH}$ $\mathrm{CaCl}_{2}$ 4.6; SMP index 5.3; soil organic matter $53.61 \mathrm{~g} \mathrm{dm}^{-3}$; phosphorus (P) and potassium (K) (Mehlich-1) $5.76 \mathrm{mg} \mathrm{dm}^{-3}$ and $0.20 \mathrm{cmol}_{\mathrm{c}} \mathrm{dm}^{-3}$, respectively; calcium $\left(\mathrm{Ca}^{2+}\right)$, magnesium $\left(\mathrm{Mg}^{2+}\right)$ and aluminum $\left(\mathrm{Al}^{3+}\right)\left(\mathrm{KCl} 1 \mathrm{~mol} \mathrm{~L}{ }^{-1}\right) 4.68,2.82$ and $0.49 \mathrm{cmol}_{\mathrm{c}} \mathrm{dm}^{-3}$, respectively; hydrogen + aluminum $\left(\mathrm{H}^{+}+\mathrm{Al}^{3+}\right) 9.62 \mathrm{cmol}_{\mathrm{c}} \mathrm{dm}^{-3}$; base saturation (V) $44.2 \%$ and aluminum saturation (m) $5.95 \%$.

The experiment was conducted in a randomized complete block design, with five treatments and four repetitions, in plots with 36 $\mathrm{m}^{2}$. On November 2005 lime was applied on soil surface in the following doses: $0,2.4,4.8$, 7.2 and 9.6 t ha- $^{-1}$ (PRNT 100\%), equivalent to the neutralization of $0,25,50,75$ and $100 \%$ of $\mathrm{H}^{+}+$ $\mathrm{Al}^{3+}$. The treatments were the lime doses and the amounts applied were calculated to neutralize the acidity in the $0.00-0.20 \mathrm{~m}$ layer.

The crops sequence implanted during the experiment was: soybean (2005/2006 crop); black oat (2006 crop); corn (2006/2007 crop); wheat (2007 crop); soybean (2007/2008 crop); black oat (2008 crop); corn (2008/2009 crop); black oat (2009 crop); and soybean (2009/2010 crop).

After the lime application eight soil 
samples were taken, on February 3, June 9 and December 20, 2006, September 12, 2007. February 14 and September 10, 2008 and May 23 and December 16, 2009, corresponding to approximately $2,6,13,22,27,34,42$ and 49 months after the lime application, respectively. Six soil layers were sampled: 0.0 to $0.025,0.025$ to $0.05,0.05$ to $0.10,0.10$ to $0.15,0.15$ to 0.20 and 0.20 to $0.40 \mathrm{~m}$, using a cutting shovel for the collection up to the depth of $0.20 \mathrm{~m}$ and a Dutch auger for the depth of $0.20-0.40 \mathrm{~m}$. These samplings were taken randomly within each plot by marking the points of collection in order to avoid more than one collection at the same local during different times. Exchangeable calcium, magnesium and aluminum contents ( $\mathrm{KCl} 1 \mathrm{M}), \mathrm{pH}-\mathrm{CaCl}_{2}$, and $\mathrm{H}^{+}+\mathrm{Al}^{3+}$, obtained through the SMP index, were measured in the collected samples. Base and aluminum saturations were calculated using these data. The laboratory methodology followed the one described in Pavan et al. (1992).

Grain yield was assessed for soybean, corn and wheat in a sampling area with 9.0, 8.4 and $9.0 \mathrm{~m}^{2}$, respectively, for each plot, and this yield was adjusted for $13 \%$ of grain humidity. To evaluate black oat dry mass, the plants were cut at the soil level in two points per plot, at the full bloom stage, using a $0.25 \mathrm{~m}^{2}$ quadrat. The samples were dried in an oven at $60^{\circ} \mathrm{C}$ until constant weight.

The results of soil chemical properties underwent analysis of variance through the $\mathrm{F}$ test $(p \leq 0.05)$ and the soil layers were evaluated separately in a split-plot arrangement, where the plots were the lime doses and the subplots the time after liming. The two factors were quantitative and when a significant interaction occurred, a response surface analysis was applied. When interaction was not significant, regression analysis for isolated factors was carried out. In such cases, the model with the highest degree of significance through the F test ( $p \leq 0.05)$ was chosen in order to explain the results. The results of grain and dry mass yield were submitted to variance analysis through the $\mathrm{F}$ test ( $\mathrm{p} \leq 0.05)$, adjusted and when significant, through regression analysis by lime doses, using the model of highest degree of significance, through the $\mathrm{F}$ test ( $\mathrm{p} \leq 0.05)$, to explain the results. The analyses were carried out by using the Assistat program, version 7.7 beta (Silva \& Azevedo, 2002).

\section{Results and Discussion}

Interactions were significant between the factors lime doses and time after liming in the 0 to $0.025 \mathrm{~m}$ layer for $\mathrm{Al}, \mathrm{Mg}$ and $\mathrm{m}$ content, and in the 0.025 to $0.05 \mathrm{~m}$ layer for $\mathrm{pH}, \mathrm{Al}, \mathrm{Ca}, \mathrm{V}$ and $\mathrm{m}$; for these variables, the response surfaces were adjusted (Table 1). Significant effect of lime doses was observed up to the 0.05 to $0.1 \mathrm{~m}$ layer for $\mathrm{pH}$, $\mathrm{Mg}$ and $\mathrm{V}$, and up to the 0.025 to $0.05 \mathrm{~m}$ layer for $\mathrm{Al}, \mathrm{Ca}$ and $\mathrm{m}$. Time after liming had a significant effect up to the 0.2 to 0.4 layer for all evaluated soil chemical properties. But in layers below those graphically presented and discussed, time had a significant effect; however, it was significantly represented only by the average doses and times after liming, which did not generate a variation in accordance to the time after liming.

The effect of the surface applied lime was more concentrated in the superficial soil layers, since the volume of soil that comes into contact with lime was low (Briedis et al., 2012). Assessing the chemical attributes related to soil acidity after seven years of superficial lime application under no-tillage system, Gatiboni et al. (2003) observed that exchangeable $\mathrm{Ca}$ and Mg decreased gradually, while exchangeable Al content presented linearly increasing values, when depth was increased. As shown by Pöttker \& Ben (1998), lime application without incorporation into the soil, in no-tillage system, influences chemical characteristics mainly in the 0-5 cm layer the 5-10 cm layer in lower intensity. Cury et al., (2014) observed that in no-tillage areas there was an increase in fertility attributes content due to lime application, as well as an increase in base saturation and calcium content only in the superficial layer.

After 49 months of the liming, a significant effect of liming on the soil $\mathrm{pH}$ was observed up to a depth of $0.1 \mathrm{~m}$ (Figure 1), increasing the values with an increase of the applied dose, confirmed by the quadratic effect in the 0 to $0.025 \mathrm{~m}$ layer (Figure 1a), parabolic in the 0.025 to $0.05 \mathrm{~m}$ (Figure 1c) and linear in the 0.05 to $0.1 \mathrm{~m}$ (Figure 1d). For the 0 to $0.025 \mathrm{~m}$, no alterations of $\mathrm{pH}$ in time were observed, while from the depth of 0.025 to $0.1 \mathrm{~m}$ 
Table 1. Variance analysis, with $\mathrm{F}$ value for the interaction between lime dose $\mathrm{x}$ time after liming and its isolated effects

\begin{tabular}{|c|c|c|c|c|c|c|c|c|}
\hline $\begin{array}{l}\text { Sources of } \\
\text { variation }\end{array}$ & $\mathrm{DF}^{1}$ & $\mathrm{DFr}^{2}$ & 0 to $0.25 \mathrm{~m}$ & 0.025 to $0.05 \mathrm{~m}$ & 0.05 to $0.1 \mathrm{~m}$ & 0.1 to $0.15 \mathrm{~m}$ & 0.15 to $0.2 \mathrm{~m}$ & 0.2 to $0.4 \mathrm{~m}$ \\
\hline & & & & & $\mathrm{pH}$ & & & \\
\hline Dose & 4 & 12 & $33.51^{* *}$ & $8.97^{* *}$ & $4.71^{*}$ & $0.11^{\mathrm{ns}}$ & $0.28^{\text {ns }}$ & $1.57^{\text {ns }}$ \\
\hline Time & 7 & 105 & $0.87^{\text {ns }}$ & $4.43^{* *}$ & $9.09 * *$ & $7.69 * *$ & $10.98^{* *}$ & $6.49 * *$ \\
\hline Dose*Time & 28 & 105 & $1.55^{\mathrm{ns}}$ & $1.73^{*}$ & $\begin{array}{l}1.21^{\mathrm{ns}} \\
\text { Aluminum }\end{array}$ & $0.64^{\mathrm{ns}}$ & $0.85^{\mathrm{ns}}$ & $1.41^{\mathrm{ns}}$ \\
\hline Dose & 4 & 12 & $43.47^{* *}$ & $16.39 * *$ & $3.03^{\mathrm{ns}}$ & $0.02^{\text {ns }}$ & $0.16^{\mathrm{ns}}$ & $1.06^{\mathrm{ns}}$ \\
\hline Time & 7 & 105 & $4.96^{* *}$ & $3.93^{* *}$ & $3.1^{* *}$ & $4.79 * *$ & $5.71^{* *}$ & $4.14^{* *}$ \\
\hline Dose*Time & 28 & 105 & $3.89 * *$ & $2.09^{* *}$ & $\begin{array}{l}0.96^{\mathrm{ns}} \\
\text { Calcium }\end{array}$ & $0.89^{\mathrm{ns}}$ & $0.52^{\mathrm{ns}}$ & $0.65^{\mathrm{ns}}$ \\
\hline Dose & 4 & 12 & $33.52 * *$ & $9.88^{* *}$ & $0.19^{\text {ns }}$ & $0.23^{n s}$ & $0.24^{\mathrm{ns}}$ & $0.65^{\mathrm{ns}}$ \\
\hline Time & 7 & 105 & $11.16^{* *}$ & $6.33^{* *}$ & $5.66^{* *}$ & $8.21^{* *}$ & $16.32 * *$ & $9.16^{* *}$ \\
\hline Dose*Time & 28 & 105 & 1.38 & $1.88^{*}$ & $\begin{array}{c}1.13^{\mathrm{ns}} \\
\text { Magnesium }\end{array}$ & $0.89^{\mathrm{ns}}$ & $0.71^{\mathrm{ns}}$ & $0.79^{\mathrm{ns}}$ \\
\hline Dose & 4 & 12 & $47.87^{* *}$ & $11.92^{* *}$ & $5.37^{*}$ & $0.94^{\mathrm{ns}}$ & $0.43^{n s}$ & $1.25^{\mathrm{ns}}$ \\
\hline Time & 7 & 105 & $7.99 * *$ & $3.97^{* *}$ & $2.6^{*}$ & $3.3^{* *}$ & $6.86^{* *}$ & $4.91^{* *}$ \\
\hline Dose*Time & 28 & 105 & $1.62 * *$ & $\begin{array}{l}1.56^{\text {ns }} \\
\text { Base }\end{array}$ & $\begin{array}{c}0.79 \text { ns } \\
\text { saturation }\end{array}$ & $1.29 \mathrm{~ns}$ & $0.76^{\mathrm{ns}}$ & $0.77^{\mathrm{ns}}$ \\
\hline Dose & 4 & 12 & $61.54^{* *}$ & $10.65^{* *}$ & $3.41^{*}$ & $0.16^{\mathrm{ns}}$ & $0.43^{\mathrm{ns}}$ & $0.86^{n s}$ \\
\hline Time & 7 & 105 & $3.46^{* *}$ & $4.37^{* *}$ & $5.1^{* *}$ & $5.09 * *$ & $9.97^{* *}$ & $5.68^{* *}$ \\
\hline Dose*Time & 28 & 105 & $1.55^{\mathrm{ns}}$ & $\begin{array}{c}1.68^{*} \\
\text { Aluminum }\end{array}$ & $\begin{array}{c}1.13^{\mathrm{ns}} \\
\text { saturation }\end{array}$ & $0.65^{\mathrm{ns}}$ & $0.68^{\mathrm{ns}}$ & $1.16^{\mathrm{ns}}$ \\
\hline Dose & 4 & 12 & $37.96^{* *}$ & $21.57^{* *}$ & $2.26^{\mathrm{ns}}$ & $0.03^{n s}$ & $0.11^{\mathrm{ns}}$ & $0.98^{\mathrm{ns}}$ \\
\hline Time & 7 & 105 & $4.51^{* *}$ & $3.24^{* *}$ & $2.65^{*}$ & $5.08^{* *}$ & $7.41^{* *}$ & $5.6^{* *}$ \\
\hline Dose*Time & 28 & 105 & $3.54^{* *}$ & $\begin{array}{c}2.2^{* *} \\
\text { Organic }\end{array}$ & $\begin{array}{l}1.08^{\mathrm{ns}} \\
\text { mater }\end{array}$ & $0.7^{\mathrm{ns}}$ & $0.5^{\mathrm{ns}}$ & $0.6^{\mathrm{ns}}$ \\
\hline Dose & 4 & 12 & $1.19^{\mathrm{ns}}$ & $0.59^{\text {ns }}$ & $0.49^{n s}$ & $0.37^{\mathrm{ns}}$ & $1.19^{\mathrm{ns}}$ & $0.45^{\mathrm{ns}}$ \\
\hline Time & 7 & 105 & $13.39 * *$ & $11.13^{* *}$ & $8.89 * *$ & $9.24^{* *}$ & $10.54^{* *}$ & $10.78^{* *}$ \\
\hline Dose*Time & 28 & 105 & $0.61^{\mathrm{ns}}$ & $0.55^{\mathrm{ns}}$ & $0.5^{\mathrm{ns}}$ & $0.8^{n s}$ & $1.46^{\mathrm{ns}}$ & $0.97^{\mathrm{ns}}$ \\
\hline
\end{tabular}

the increase of $\mathrm{pH}$ according to liming occurred up to 34 months; after this period the effect of liming on soil pH increase was not observed.

Exchangeable aluminum content (Figure 2) and aluminum saturation (Figure 3) presented similar responses to lime application and obtained significant interactions of the lime doses with the time after liming up to a depth of $0.05 \mathrm{~m}$, with a parabolic response, whith a decrease of exchangeable aluminum content and its saturation when lime dose was increased. Both also increased over time and there was a return of aluminum in its exchangeable form to the soil.

Exchangeable calcium content (Figure 4), up to a depth of $0.05 \mathrm{~m}$ was higher with an increase of the applied doses. However, it was observed that in the 0 to $0.025 \mathrm{~m}$ layer this content reduced linearly according to time after lime application; for the 0.025 to $0.05 \mathrm{~m}$ layer the behavior was the opposite, with an increase in the content. Exchangeable magnesium content (Figure 5) was increased due to liming up to the depth of $0.1 \mathrm{~m}$ with an increase in the applied lime dose. In the 0 to $0.25 \mathrm{~m}$ layer, a reduction of the content over time after liming was observed, similar to the effect of liming on the exchangeable calcium content; while in the 0.025 to $0.05 \mathrm{~m}$ the effect followed the average and was linear in the 0.05 to 0.1 layer with an increase during the evaluated time. Fidaklski \& Tormena (2005) also observed alterations of magnesium content in deeper layers when compared to calcium content in no-tillage area with surface lime application.

Base saturation (Figure 6) was influenced by liming up to a depth of $0.01 \mathrm{~m}$, with higher contents with an increase of the applied doses; the observations were more evident for the 0 to $0.025 \mathrm{~m}$ layer, mainly due to a reduction on the exchangeable aluminum content, an increase on the exchangeable calcium and magnesium 
content in the 0.025 to $0.05 \mathrm{~m}$ layers and an increase on exchangeable magnesium in the 0.05 to $0.1 \mathrm{~m}$ layer.
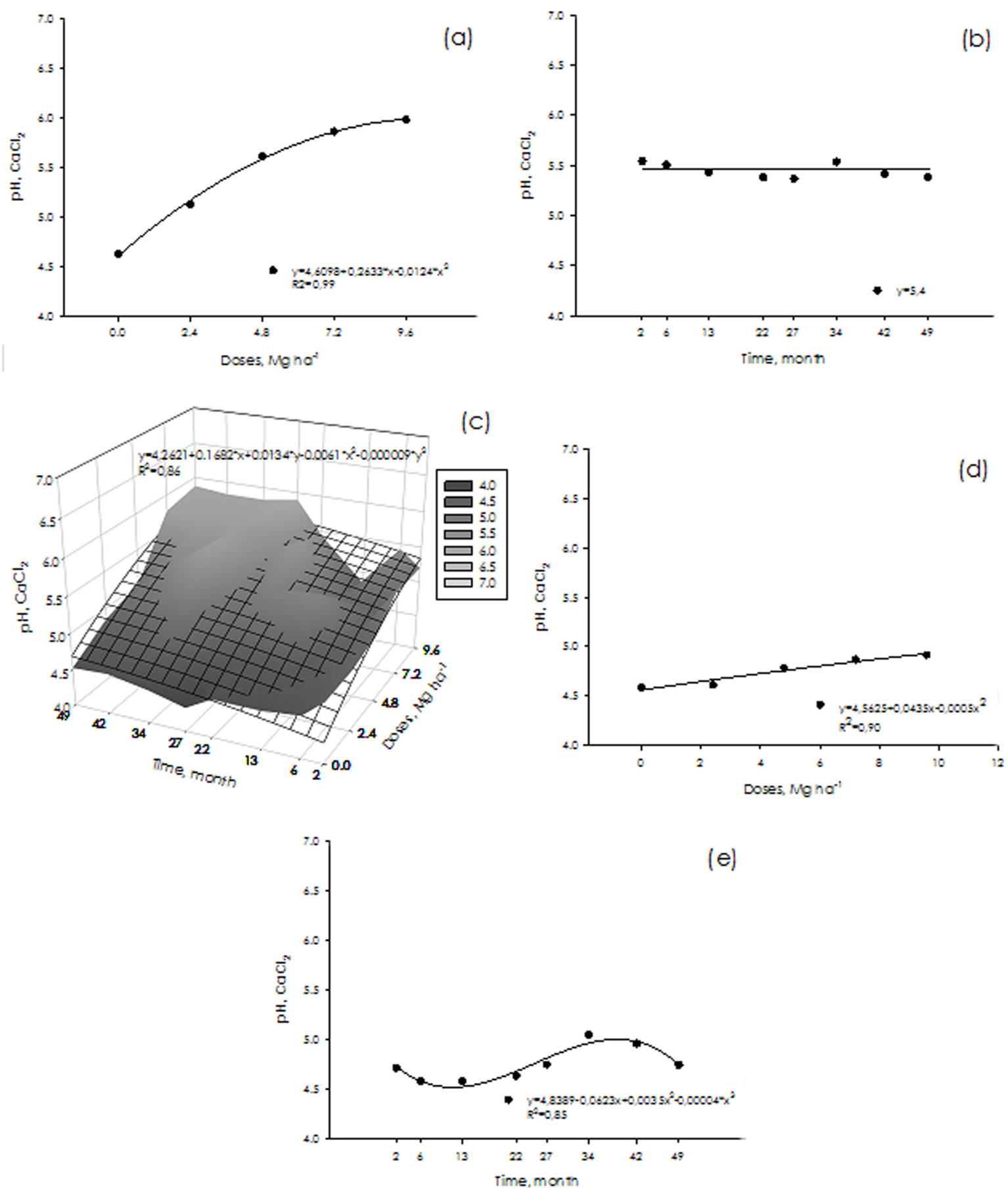

Figure 1. Effect of the application of five lime doses over time (eight soil samplings) on the soil pH in no-tillage system. (a) isolated effect of lime doses on the 0 to $0.025 \mathrm{~m}$ layer; (b) isolated effect of sampling time on the 0 to $0.025 \mathrm{~m}$ layer; (c) effect of dose and time interaction on the 0.025 to $0.05 \mathrm{~m}$ layer; (d) isolated effect of lime doses on the 0.05 to $0.1 \mathrm{~m}$ layer; $\square$ isolated effect of sampling time on the 0.05 to $0.1 \mathrm{~m}$ layer $(\mathrm{p} \leq 0.05)$. 

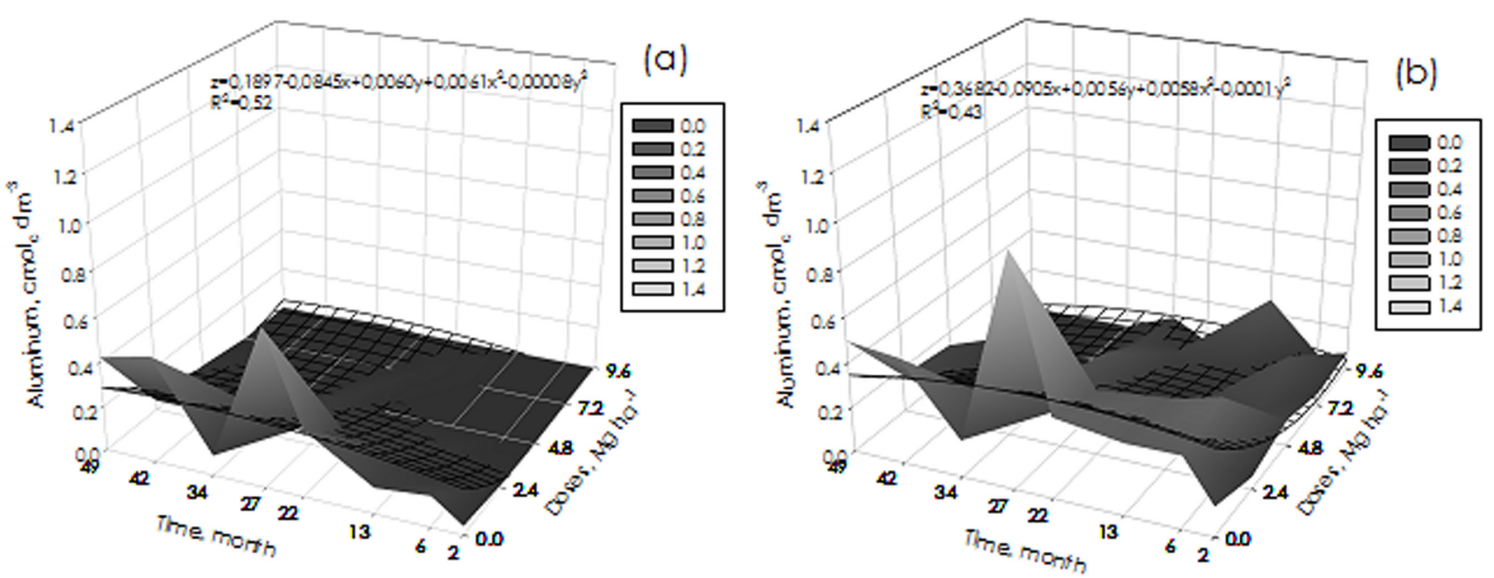

Figure 2. Effect of the application of five lime doses over time (eight soil samplings) on the content of exchangeable aluminum in the soil with no-tillage. (a) interaction of dose and time on the 0 to $0.025 \mathrm{~m}$ layer; (b) interaction of dose and time on the 0.025 to 0.05 m layers $(p \leq 0.05)$.
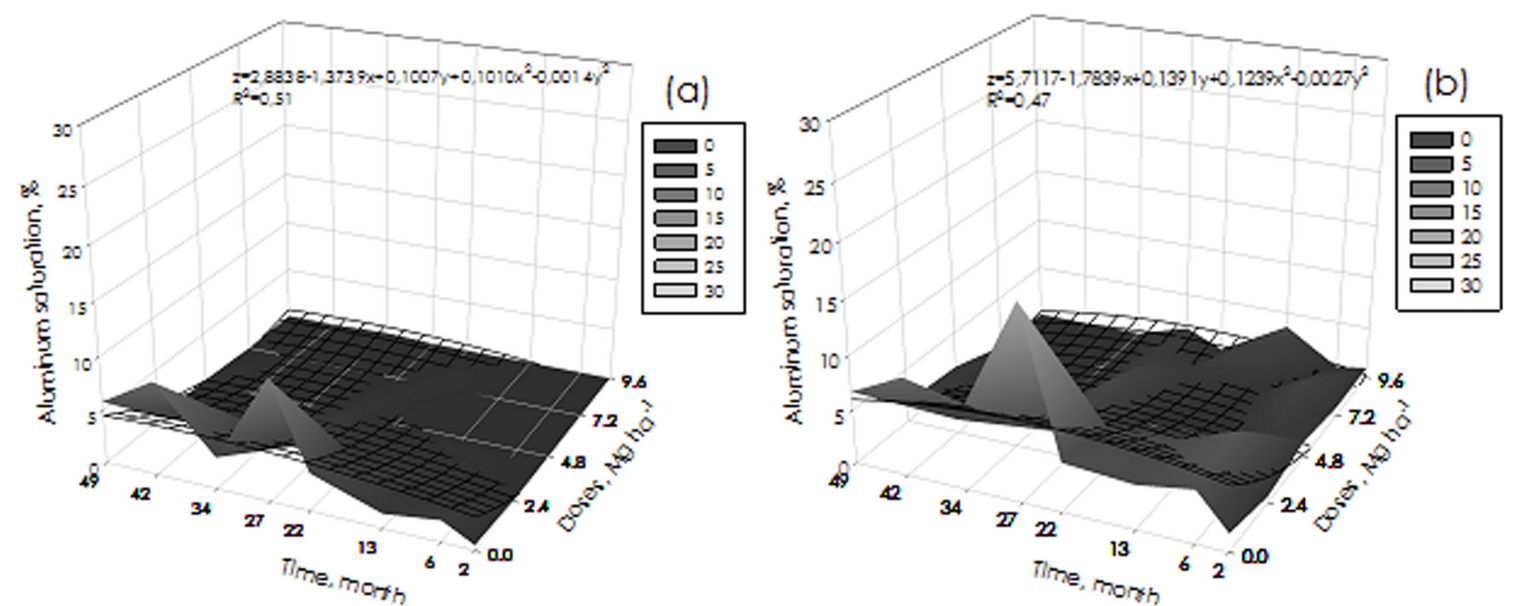

Figure 3. Effect of the application of five doses of lime over time (eight soil samplings) on the no-tillage soil aluminum saturation. (a) effect of the interaction of dose and time on the 0 to $0.025 \mathrm{~m}$ layer; (b) effect of the interaction of dose and time on the 0.025 to 0.05 m layers $(\mathrm{p} \leq 0.05)$. 

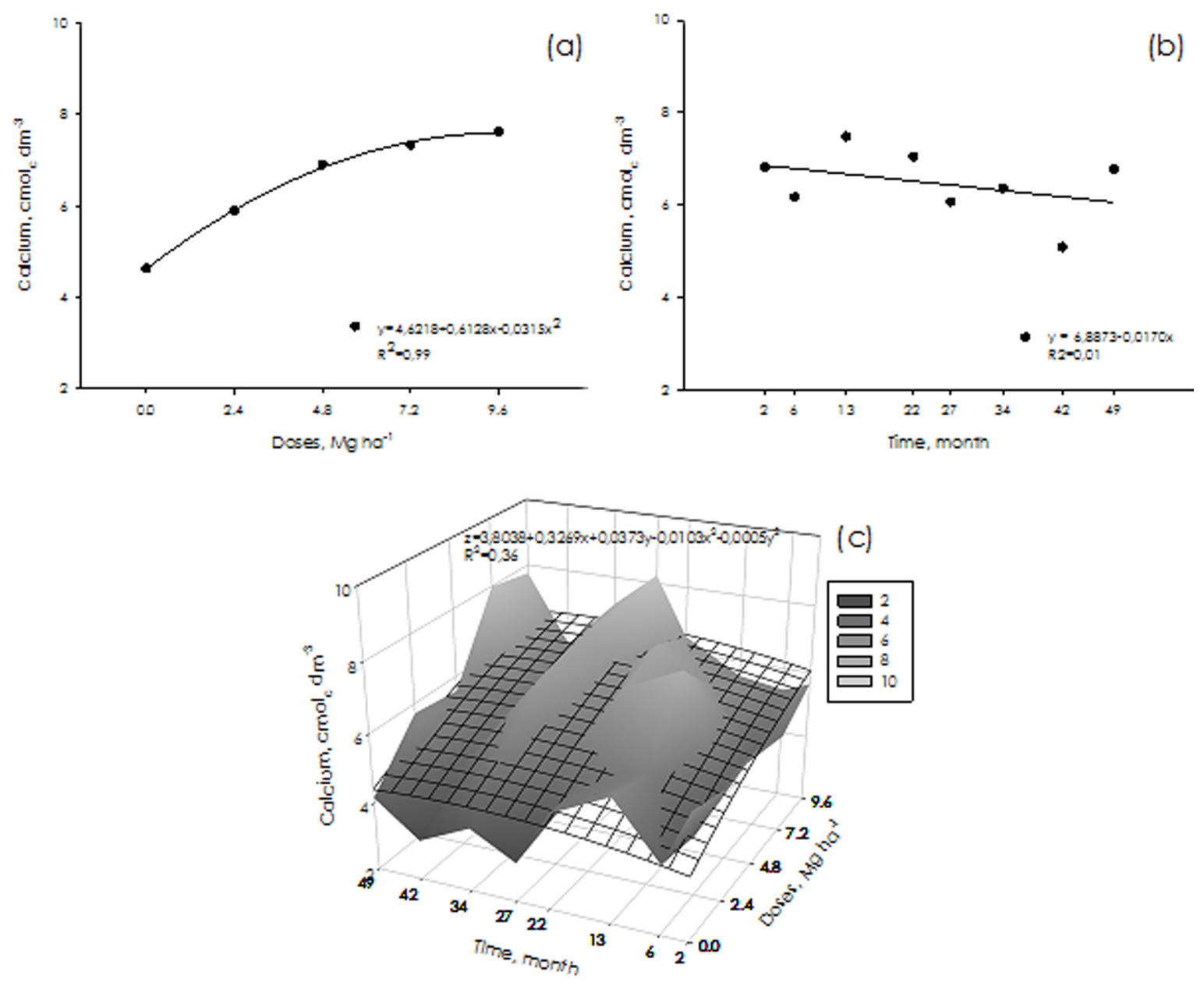

Figure 4. Effect of the application of five doses of lime over time (eight soil samplings) on the exchangeable calcium content in a no-tillage area. (a) isolated effect of lime doses on the 0 to $0.025 \mathrm{~m}$ layer; (b) isolated effect of sampling time on the 0 to $0.025 \mathrm{~m}$ layer; c) effect of the interaction between dose and time on the 0.025 to $0.05 \mathrm{~m}$ layer ( $p \leq 0.05)$. 

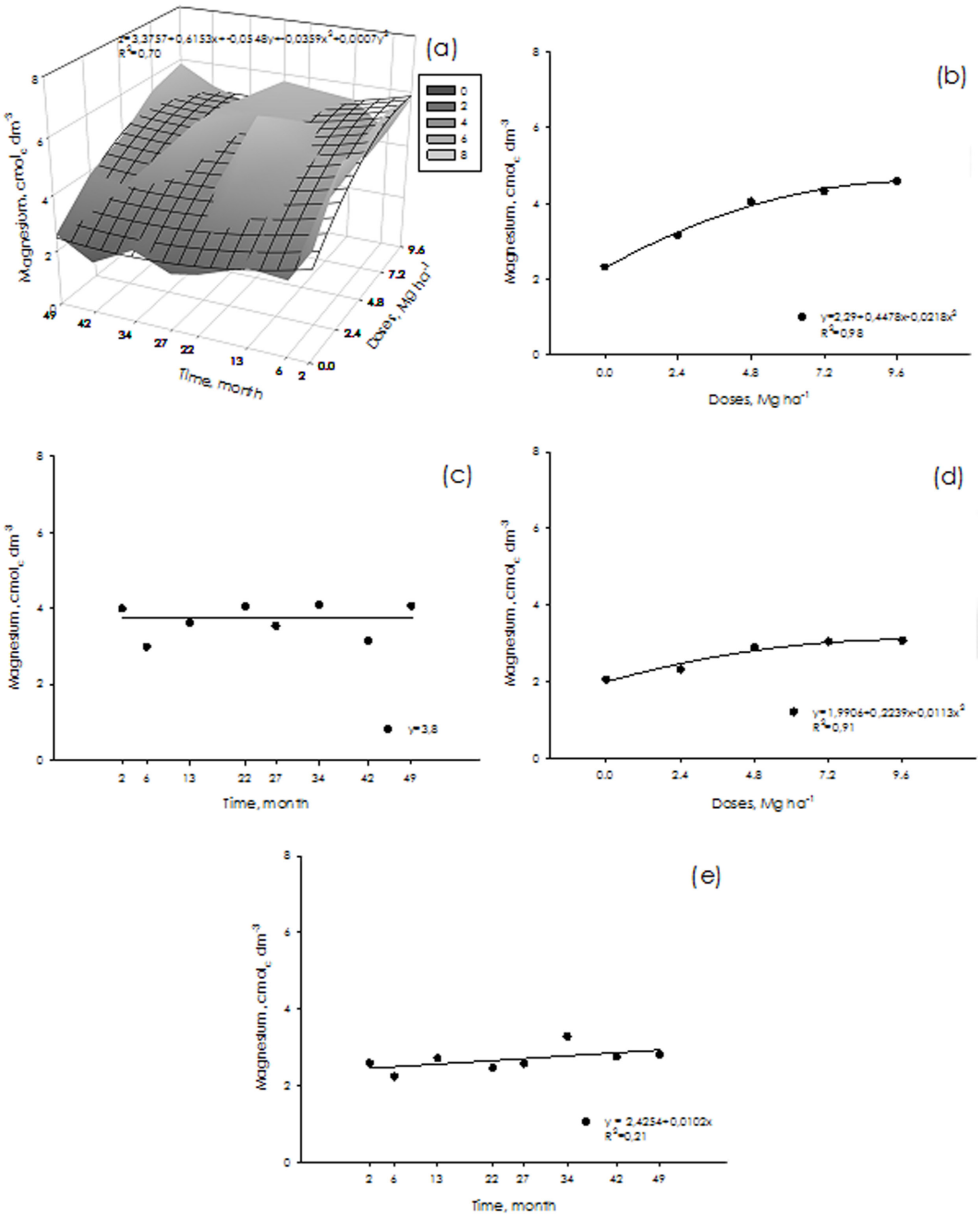

Figure 5. Effect of the application of five doses of lime over time (eight soil samplings) on the exchangeable magnesium content in a no-tillage area. (a) effect of the interaction of doses and time on the 0 to $0.025 \mathrm{~m}$ layer; (b) isolated effect of lime doses on the 0 to $0.025 \mathrm{~m}$ layer; (c) isolated effect of sampling time in the 0.025 to $0.05 \mathrm{~m}$ layer; (d) isolated effect of lime doses on the 0.05 to $0.1 \mathrm{~m}$ layer; (e) isolated effect of sampling time on the 0.05 to $0.1 \mathrm{~m}$ layer ( $\mathrm{p} \leq 0.5)$. 

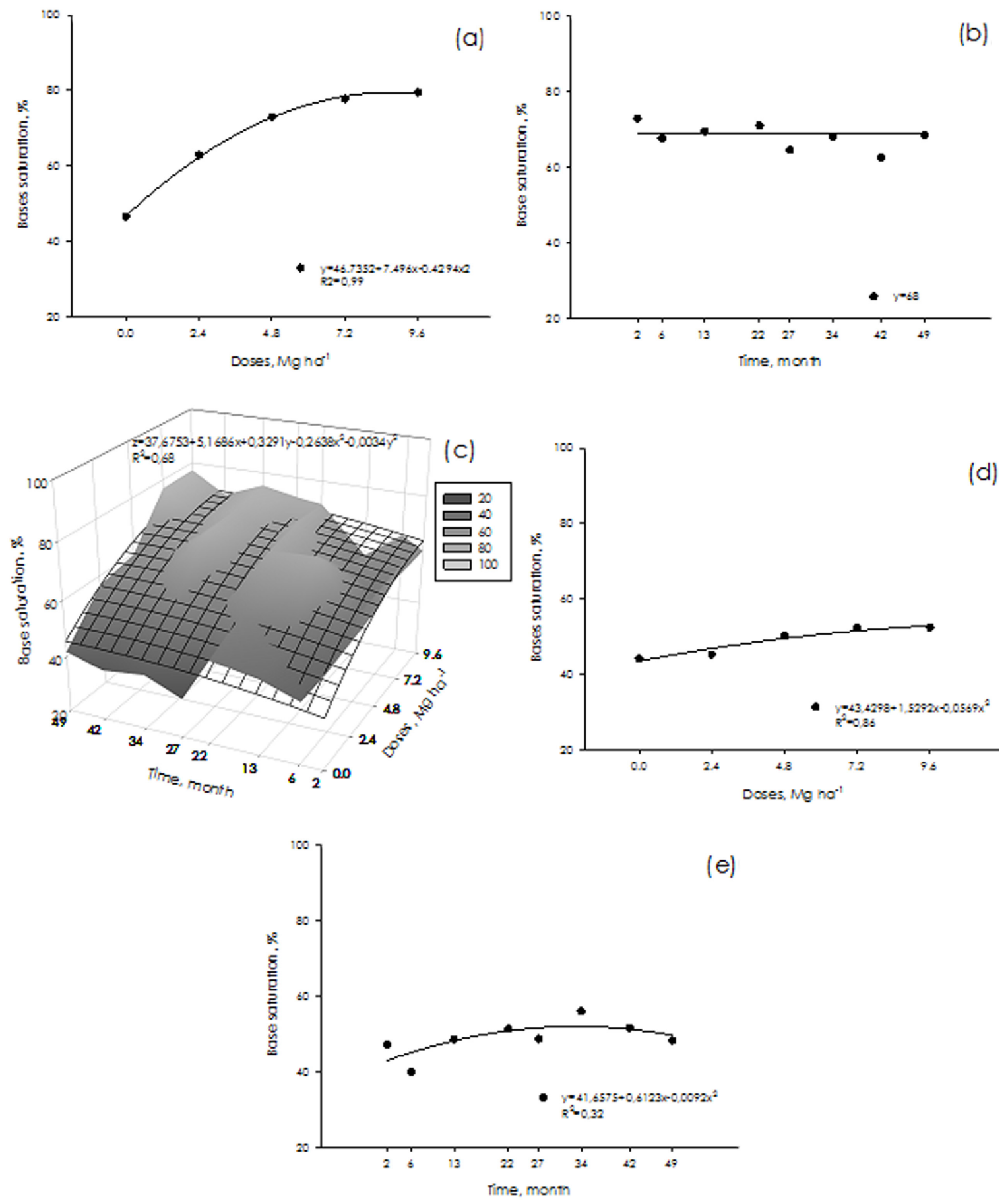

Figure 6. Effect of the application of five doses of lime over time (eight soil samplings) on base saturation in a no-tillage area. (a) isolated effect of lime doses on the 0 to $0.025 \mathrm{~m}$ layer; (b) isolated effect of the time sampling on the 0 to $0.025 \mathrm{~m}$ layers; (c) effect of the interaction between dose and time on the 0.025 to $0.05 \mathrm{~m}$ layer; (d) isolated effect of the doses of lime on the 0.05 to 0.1 $\mathrm{m}$ layer; $\square$ isolated effect of sampling time on the 0.05 to $0.1 \mathrm{~m}$ layer ( $\mathrm{p} \leq 0.05$ ). 
The grain yield of the studied crops during the experimental period is shown in Table 2. The yield observed for soybean (2005/06 and 2007/08 crop years), corn (2006/07 and 2008/09 crop years) and wheat (2007 crop year) were not influenced by the surface liming, as well as the accumulated yield for all grain crops. The absence of response to the liming in no-tillage, in a soil with moderate acidity, was also observed by Caires et al. (2000), but these authors found a significant effect of liming on the accumulated grain yield, differing from the data found in this

Table 2. Yield of grains in a sequence of crops in no-tillage system with application of lime doses on the surface

\begin{tabular}{|c|c|c|c|c|c|c|c|}
\hline Lime & $\begin{array}{l}\text { Soy } \\
(2005 / 06)\end{array}$ & $\begin{array}{c}\text { Corn } \\
(2006 / 07)\end{array}$ & $\begin{array}{l}\text { Wheat } \\
\text { (2007) }\end{array}$ & $\begin{array}{c}\text { Soy } \\
(2007 / 08)\end{array}$ & $\begin{array}{c}\text { Corn } \\
(2008 / 09)\end{array}$ & $\begin{array}{c}\text { Soy } \\
(2009 / 10)\end{array}$ & $\begin{array}{l}\text { Accumulated } \\
\text { yield }\end{array}$ \\
\hline $\mathrm{Mg} \mathrm{ha}^{-1}$ & & \multicolumn{5}{|c|}{$\mathrm{kg} \mathrm{ha}^{-1}$} & \\
\hline 9.6 & 3325 & 8409 & 2231 & 2341 & 7410 & 3739 & 27455 \\
\hline 7.2 & 3213 & 9457 & 1988 & 2209 & 6795 & 4114 & 27774 \\
\hline 4.8 & 2875 & 9290 & 1983 & 2299 & 7428 & 3981 & 27856 \\
\hline 2.4 & 3091 & 9628 & 1879 & 2248 & 7112 & 4474 & 28431 \\
\hline 0 & 2982 & 8759 & 2073 & 2209 & 7250 & 3735 & 27008 \\
\hline Value of $F$ & 2.01 & 1.81 & 0.57 & 0.078 & 0.27 & $6.51^{* *}$ & 0.56 \\
\hline C.V. (\%) & 8.13 & 8.28 & 17.12 & 18.45 & 13.82 & 5.99 & 5.05 \\
\hline
\end{tabular}

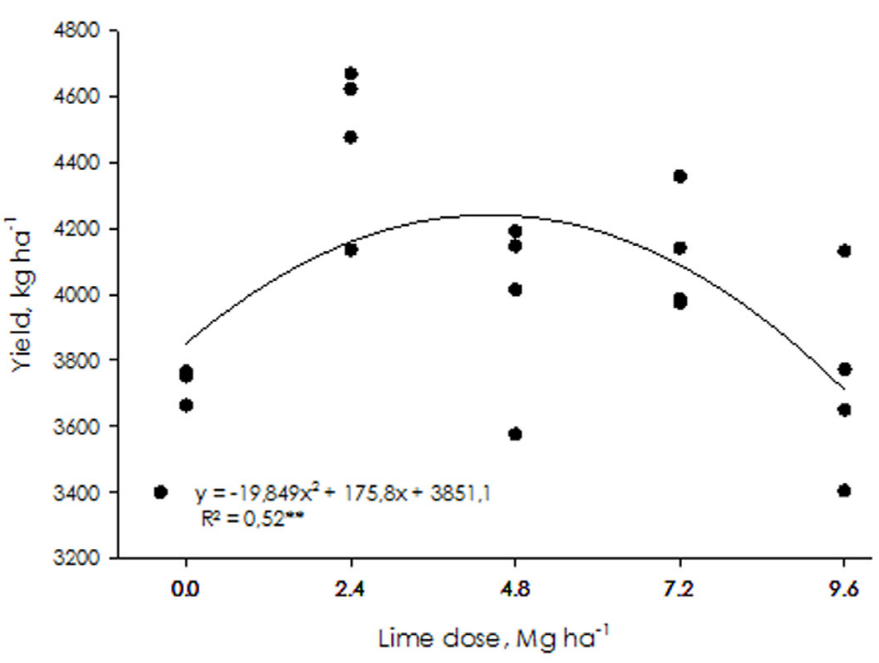

Figure 7. Effect of the surface application of lime doses on soybeans yield in no-tillage system during the 2009/2010 crop year. Averages of four repetitions. ** Significant $\mathrm{P} \square 0.01$

study. Studying the sequence between wheat and soybean in no-tillage systems in Argentina, Barbieri et al. (2015) observed that there was no effect of liming on the wheat grain productivity and there was a significant increase of the soybean productivity.

However, for the last evaluated crop year (2009/10) (Figure 7) there was a significant effect of the lime doses on the soybean grain yield. The lower yields were observed in the two extremes of liming doses, indicating that intermediate lime doses were more appropriate for this crop. Based on the regression equation obtained for the soybean (2009/10), the maximum technical efficiency (MTE) and maximum economical efficiency (MEE) were estimated. Both were observed when the lime dose of $4.4 \mathrm{Mg} \mathrm{ha}^{-1}$ was applied. MEE was calculated by using the prices of $R \$ 510.00$ and $R \$ 52.00$ per $\mathrm{Mg}$ for soybean and lime, respectively, based on the prices paid by producers (SEAB, 2010); for soybean the value refers to April, 2010 and the lime used was Dolomitic, corresponding to November, 2005.

Caires et al. (2000) attributed the decrease in grain yield in the higher lime doses to the decrease of zinc and manganese absorption by the cultures, due the increase of soil $\mathrm{pH}$ provided by the liming. It is important to highlight that, for the first time in the experiment, transgenic soybean was cultivated, a fact that may explain 
the positive effects of lime up to moderate doses (Figure 6) and its decrease in higher doses, since there are studies indicating restrictions to the manganese absorption from the soil in transgenic soybean crops (Gordon, 2007).

The dry mass productivity of black oat in no-tillage system, with surface application of lime doses may be observed in Table 3. It is noted that both for the three cultivations of black oat and for the accumulated dry mass productivity, there was no significant effect of the liming.

Similar results were reported by Caires et al. (2000) in which the application of lime doses on the soil surface did not resulted in a significant influence on soybean dry mass productivity in an assessment carried out after 3 years of cultivation. Caires et al. (1998) observed that soybean did not respond to the surface application of lime and gypsum in a soil with $\mathrm{pH}-\mathrm{CaCl}_{2}$ of 4.5 in the 0-20 cm layer. Therefore, the no-tillage system, even in conditions of acidity, shows that it is possible to obtain high productivity as long as the content of calcium, manganese and potassium are sufficient and the aluminum content is not

Table 3. Dry mass of black oat cultivated in no-tillage system with surface application of lime doses.

\begin{tabular}{ccccc}
\hline \multirow{2}{*}{ Lime } & \multicolumn{3}{c}{ Year } & \multirow{2}{*}{$\begin{array}{c}\text { Accumulated } \\
\text { Yield }\end{array}$} \\
\cline { 2 - 4 } Mg ha $^{-1}$ & 2006 & 2008 & 2009 & \\
9.6 & 5180 & 7050 & $\mathrm{~kg} \mathrm{ha}^{-1}$ & 16730 \\
7.2 & 5520 & 6960 & 3900 & 16430 \\
4.8 & 4955 & 6760 & 3900 & 15615 \\
2.4 & 5035 & 5865 & 3600 & 14500 \\
0.0 & 4985 & 6230 & 3500 & 14715 \\
F value & 0.79 & 2.61 & 0.61 & 0.13 \\
C.V. (\%) & 10.15 & 9.55 & 25.76 & 8.63 \\
\hline
\end{tabular}
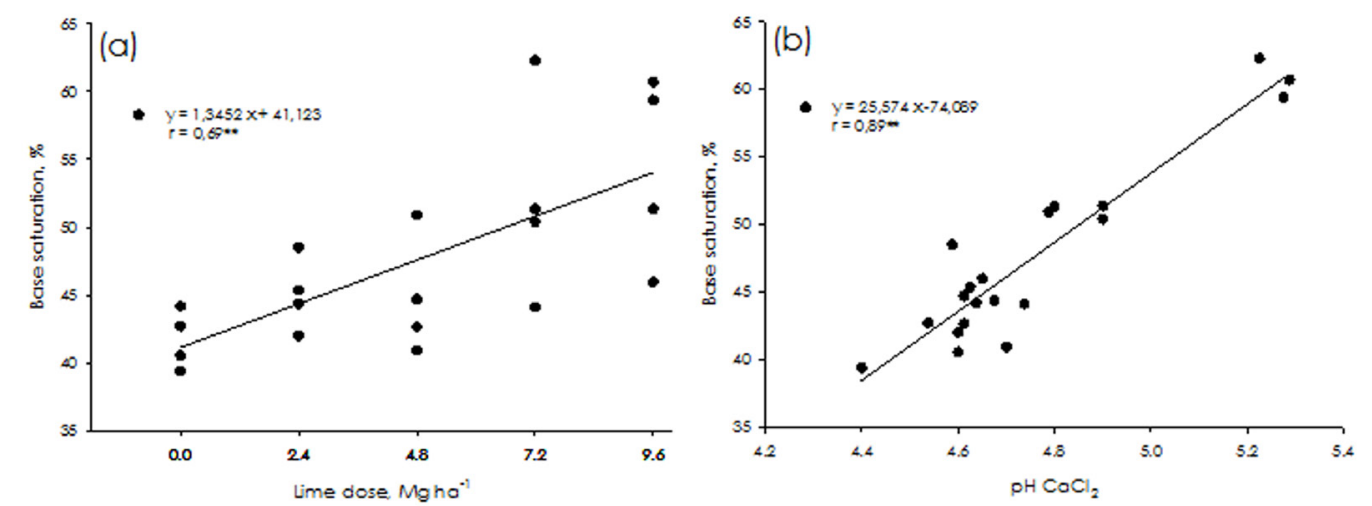

Figure 8. Relationship between lime doses applied on surface and base saturation in a consolidated no-tillage area (a) and between $\mathrm{pH}$ in $\mathrm{CaCl}_{2}$ and base saturation for the $0-0.20$ m layer in soil collection at 49 months. ${ }^{* *}$ Significant $\mathrm{P}<0.01$.

too high. For their part, Corrêa et al. $(2007 ; 2008)$ observed an increase in the root system and canopy growths of black oat with the surface application of acidity correctives, such as lime in no-tillage system. Zandoná et al. (2015) observed an increase in productivity of soybean with the use of correctives gypsum and lime in Red Oxisol in no-tillage system.

The suggested base saturation index in consolidated no-tillage system was 50\%, for the studied conditions, close to the dose calculated for the attainment of MET and MEE, in the 0.00-0.20 m layer, at 49 months after liming, as demonstrated by the relationship between the applied lime doses and the base saturation (Figure 8a). The relationship between $\mathrm{pH}-\mathrm{CaCl}_{2}$ and base saturation showed that the ideal $\mathrm{pH}$ in order to obtain a base saturation around 50\% was 4.9 (Figure 8b). These results differ from those found by Caires et al. (2000), who suggested a base saturation index of $65 \%$ and found a maximum accumulated production of grains at the lime dose of $3.3 \mathrm{Mg} \mathrm{ha}^{-1}$.

Considering that in this study there was no difference in the accumulated grain yield and dry mass yield of black oat, MEE was in 
the treatment without liming, presenting a base saturation (average for eight collections) about $50 \%$ and a pH-CaCl of 4.6 . From these data it may be inferred that a base saturation value of $50 \%$ in the $0.00-0.20 \mathrm{~m}$ layer tends to be the most appropriate for the main annual crops, in consolidated no-tillage system, as long as the organic matter content is high, which may reduce the toxic effect of the aluminum ion.

\section{Conclusions}

The application of surface liming in consolidated no-tillage system reduces the soil aluminum content and increases the magnesium content, base saturation and soil $\mathrm{pH}$ up to a depth of $0.10 \mathrm{~m}$, after 49 months of application.

Except for one cultivation with transgenic soybean, which presented response to liming, the remaining cultivations, i.e, two crops of soy, one crop of wheat, two crops of corn and three productions of dry mass of black oats, were not affected by the lime application.

From the yield data obtained in consolidated no tillage area and with high organic matter contents, it is possible to suggest that the value of $50 \%$ of base saturation may be the most appropriate for the main annu $\square$ al crops in this system.

\section{References}

Amaral, A.S., Anghinoni I. 2001. Alteração de parâmetros químicos do solo pela reaplicação superficial de calcário no sistema plantio direto. Pesquisa Agropecuária Brasileira 36:695-702.

Barbieri, P.A., Echeverría, H.E., Sainz Rozas, H.R., Martínez, J.P. 2015. Soybean and wheat response to lime in no-till Argentinean mollisols. Soil \& Tillage Research 152:29-38.

Barbosa Filho, M.P., Fageria, N.K., Zimmermann, F.J.P. 2005. Atributos de fertilidade do solo e produtividade do feijoeiro e da soja influenciados pela calagem em superfície e incorporada. Ciência e Agrotecnologia 29:507-514.

Briedis, C., Sá, J.C.M., Caires, E.F., Navarro, J.F., Inagaki, T.M., Ferreira, A.O. 2012. Carbono do solo e atributos de fertilidade em resposta à calagem superficial em plantio direto. Pesquisa Agropecuária Brasileira 47:1007-1014.

Caires, E.F., Chueiri, W.A., Madruga, E.F., Figueiredo, A. 1998. Alterações de características químicas do solo e resposta da soja ao calcário e gesso aplicados na superfície em sistema de cultivo sem preparo do solo. Revista Brasileira de Ciência do Solo 22:27-34.

Caires, E.F., Banzatto, D.A.; Fonseca, A.F. 2000. Calagem na superfície em Sistema Plantio Direto. Revista Brasileira de Ciência do Solo 24:161-169.

Caires, E.F., Haliski, A., Bini, A.R., Scharr, D.A. 2015. Surface liming and nitrogen fertilization for crop grain production under no-till management in Brazil. European Journal of Agronomy 66:41-53.

Corrêa, J.C., Büll, L.T, Crusciol, C.A.C., Marcelino, R., Mauad, M. 2007. Correção da acidez e mobilidade de íons em Latossolo com aplicação superficial de escória, lama cal, lodos de esgoto e calcário. Pesquisa Agropecuária Brasileira 42:1307-1317.

Corrêa, J.C., Büll, L.T., Crusciol, C.A.C., Fernandes, D.M, Peres, M.G.M. 2008. Aplicação superficial de diferentes fontes de corretivos no crescimento radicular e produtividade da aveia preta. Revista Brasileira de Ciência do Solo 32:1583-1590.

Chatzistathis, T., Alifragis, D., Papaioannou, A. 2015. The influence of liming on soil chemical properties and on the alleviation of manganese and copper toxicity in Juglans regia, Robinia pseudoacacia, Eucalyptus sp. and Populus sp. plantations. Journal of Environmental Management 150:149-56.

Cury, T.N., De Maria, I.C., Bolonhezi, D. 2014. Biomassa radicular da cultura de cana-deaçúcar em sistema convencional e plantio direto com e sem calcário. Revista Brasileira de Ciência do Solo 38:1929-1938.

Diehl, R.C., Miyazawa, M. Takahashi, H.W. 2008. Compostos orgânicos hidrossolúveis de resíduos vegetais e seus efeitos nos atributos químicos do solo. Revista Brasileira de Ciência do Solo 32:2653-2659.

Embrapa. 2013. Sistema brasileiro de classificação de solos. Embrapa, Brasília, Brasil. 353 p.

Fidalski, J. \& Tormena, C.A. 2005. Dinâmica da calagem superficial em um Latossolo Vermelho distrófico. Revista Brasileira de Ciência do Solo 29:235-247.

Gatiboni, L.C., Saggin, A., Brunetto, G., Horn, D., Flores, J.P.C., Rheinheimer, D.S., Kaminski, J. 2003. Alterações nos atributos químicos de solo arenoso pela calagem superficial no sistema plantio direto consolidado. Ciência Rural 33:283290.

Gordon, B. 2007. Manganese nutrition of glifosate-resistant and conventional soybeans. Better Crops 9:12-13. 
Mosquera-Losada, M.R., Rigueiro-Rodríguez, A., Ferreiro-Domínguez, N. 2015. Effect of liming and organic and inorganic fertilization on soil carbon sequestered in macro-and microaggregates in a 17-year old Pinus radiata silvopastoral system. Journal of Environmental Management 150:2838.

Nicolodi, M., Anghinoni, I., Gianello, C. 2008. Relações entre os tipos e indicadores de acidez do solo em lavouras no sistema plantio direto na região do Planalto do Rio Grande do Sul. Revista Brasileira de Ciência do Solo 32:1217-1226.

Nolla, A., Anghinoni, I. 2006. Critérios de calagem para a soja no sistema Plantio Direto consolidado. Revista Brasileira de Ciência do Solo 30:475-483.

Nolla, A. Schlindwein, J.A. Amaral, A.S. Anghinoni, I. 2005. Indicadores para a tomada de decisão de calagem no sistema plantio direto. Revista Brasileira de Agrociência 11:471-476.

Pagani, A., Mallarino, A.P. 2015. On-Farm Evaluation of Corn and Soybean Grain Yield and Soil pH Responses to Liming. Agronomy Journal 107:71-82.

Pavan, M.A., Bloch, M.F., Zempulski, H.C., Miyazawa, M., Zocoler, D. 1992. Manual de análises químicas de solo e controle de qualidade. IAPAR, Londrina, Brasil. p. 40.

Pöttker, D., Ben, J.R. 1998. Calagem para uma rotação de culturas no sistema plantio direto. Revista Brasileira de Ciência do Solo 22:675-684.

Schoninger, E.L., Lange, A., da Silva, A.F., Lemke, A.F., Monteiro, S., da Silva, J.A.N. 2010. Atributos químicos do solo e produtividade da cultura de soja em área de semeadura direta após calagem superficial. Semina: Ciências Agrárias $31: 1253-1262$.

Silva, F.A.S. \& Azevedo, C.A.V. 2002. Versão do programa computacional Assistat para $\mathrm{O}$ sistema operacional Windows. Revista Brasileira de Produtos Agroindustriais 4:71-78.

SEAB. 2010. Pesquisa de preços pagos pelos produtores. <http://www.seab.pr.gov.br/>. $<$ December 10, 2010>.

Veronese, M.F., Eros, A.B., Zancanaro, L., Rosolem, C.A. 2012. Plantas de cobertura e calagem na implantação do sistema plantio direto. Pesquisa Agropecuária Brasileira 47:1 158-1165.

Zandona, R., Beutler, A.N., Burg, G., Barreto, C.F., Schmidt, M.R. 2015. Gesso e calcário aumentam a produtividade e amenizam o efeito do déficit hídrico em soja e milho. Pesquisa Agropecuária Tropical 45:1-10. 